\title{
Krashen's Second Language Acquisition Theory in Business English Teaching
}

\author{
Yan Sun \\ School of Foreign Languages, Guangdong Pharmaceutical University, \\ Guangzhou, 510006, China
}

*Educational Reform Project of Guangdong Province"The Application of Blended English Teaching Modes in Medical and Pharmaceutical Colleges"

Keywords: Krashen's second language acquisition theory; Business English; Teaching

\begin{abstract}
One of the theories of far-reaching influence in modern language teaching theory is Krashen's second language acquisition theory. With the gradual deepening of English education, some teaching defects were gradually exposed. It is necessary for domestic universities to borrow Krashen's second language acquisition theory, which is of great benefit to the study of second language. The application of Krashen's second language acquisition theory in Business English teaching is analyzed in this paper.
\end{abstract}

The theory of second language acquisition was proposed by Krashen in 1981, which is of the greatest influence on the field of second language acquisition. This theory systematically and completely elaborates the process of second language acquisition. It is the study of the learning process of second language acquisition, which is the study of the internal relations between English as a second language and learners. This theory has been widely used in English teaching for second language classroom teaching methods, means, mode and so on, which provides a reforming theoretical basis for second language teaching and has great guiding significance.

\section{The current situation of business English teaching in China}

\section{A. The current situation of English teaching in domestic colleges and universities}

The introduction of Krashen's second language acquisition theory in our country began in the 1980s, and the teaching effect was not ideal, although a variety of methods were adopted, because many colleges and universities still do not regard English as a second language, which is a serious positioning error. Although English has gained more and more attention in our country, Krashen's second language acquisition theory has no substantial functions to English teaching. The deep-rooted concept of traditional education makes English a foreign language, which is rarely used in life and on other occasions, and just exists in classroom. Second language is different, which has a wide range of applications in the community and is the most important language apart from mother tongue. English teaching is generally guided for examinations and the objective is to obtain relevant certificates, so the practical role of English teaching is ignored and English exists as a tool for examinations. The teaching materials and classroom form the main environment of foreign language. There is a big difference in language environments, so we cannot reach the requirements of Krashen's second language acquisition theory with too little input and it is not conducive to English communication. Immigration model and Singapore model are the two main modes of English learning as a second language. Immigration model refers to the style used by someone immigrating to English-speaking countries, so there is no way to communicate in his own familiar language with other people. English is bound to become a second language. Singaporeans take English as their official language, and most of them take Chinese as their mother tongue; therefore English is a second language. So the purposes of the two are different in essence. In addition, it is difficult for Chinese learners to improve foreign language communication under the influence of the constrains of environment and other factors, whereas second language application ability and communication ability of Singaporeans can reach the level of their mother tongue because most of 
the time they are in English environment.

$B$. The deficiencies of current Business English teaching

1). The missing of real environment in language input

The teaching content of Business English teaching in many colleges and universities is abstract and lack of modernity. Traditional English teaching model is still in use. Students themselves do not have high enthusiasm in participating in classroom activities, and it is difficult to form a real sense of interaction between students and teachers.

2). The input is insufficient

Many students majoring in Business English are exposed to limited business English teaching materials; The varieties of Business English materials students should get are in serious shortage. The input is certainly not enough.

3). The prevalence of student anxiety

In participating classroom activities such as role play, many students are more prone to anxiety and tension. They are worried that they may make mistakes in classroom activities or are even reluctant to participate in classroom teaching activities.

\section{Krashen's second language acquisition theory}

Krashen believes that learning is a conscious activity, and the knowledge accessed is through others' explanation, focusing on the form of learning; language learning is a subconscious learning activities, focusing on language functions. The basis of Krashen's hypothesis series is acquisition-learning hypothesis. Monitoring hypothesis ensures that language output is not wrong, and before the output of language, the brain will first make the monitoring and editing under awareness and by use of learning results. In the process of language learning, learning and acquisition have their own laws. Teaching should follow a certain order; the reason is that, in learning English, people are more likely to master continuous tense, and then past tense. The core of Krashen's second language acquisition theory is input hypothesis, which is that only understandable language input can produce acquisition, and mainly explains how the acquisition is made. Thus, formula " $\mathrm{i}+1$ " is used by Krashen. The language material slightly higher than learners' current level is represented by "1", and the current level of the learners is represented by "i"; the ideal input needs to be relevant and interesting, and language materials need to be understood with enough input. Since emotions have a great impact on language learning results, even if the above conditions are available, it does not entirely mean that learners can learn a second language. Hence, they can absorb the language through emotional filter.

\section{A. Emotional filter hypothesis}

Anxiety, self-confidence and motivation are three types of emotional factors divided by Krashen. This assumption is that emotion plays a role in second language acquisition process. Krashen argues that those who can learn words better and faster are those who have strong self-confidence, strong motives, and greater anxiety. Emotional factors promote the input or prevent the input from entering language learning mechanism.

\section{B. Monitoring hypothesis}

This hypothesis is that only by learning can learners produce fluent second language discourse and cultivate their sense of language. Learning and acquisition play different roles in language learning process. Before they speak or write, learners monitor the correctness of the language form. The acquired language rules may only work as monitor.

C. Acquisition-learning hypothesis

Adults have two different ways to obtain a second language: learning and acquisition. This is the most basic hypothesis in Krashen's five hypotheses. Krashen argues that learning is a natural process of developing learners' language skills. It is a subconscious process in which learners judge whether their language is accurate by means of speaking language. Krashen pointed out that with the acquisition of a second language, learning is a conscious understanding of language rules and the role of learning is to play a part in monitoring the use of language. 


\section{Input hypothesis}

This hypothesis explains the generation of learning and is the core of the whole theory. The pattern is " $i+1 "$. " 1 " refers to the language material slightly higher than learner's current level, and "i" is the current level of the learner.

E. Natural order hypothesis

Learners first acquire one grammatical structure, and then acquire other grammatical structures, which are roughly the same in their grammatical structures.

\section{The application of KRASHEN'S second language acquisition theory in business English teaching}

\section{A. Providing students with a large number of Business English input}

Now concerning with business English teaching in our country, understandable input, which is stressed in Krashen's input hypothesis, is mainly offered in the form of classroom language input. In such a situation, the input quality and quantity are not guaranteed. Business English teachers' language proficiency is, of course, higher than that of students. They should focus on the difficulty coefficient of Business English teaching materials, and also provide students with a large number of Business English materials. Business English teachers have to make full use of some foreign Business English websites, etc., where authentic business English materials exist, which not only can provide a large number of business English input to the students, but also can attract students' interest. For example, on the topic of business relationship, the teacher cannot only show students other countries' e-commerce sites like those of India, the United States, Germany, Singapore, and France, but also the two local e-commerce sites in English: global resources and Alibaba. After the introduction, some Chinese exporters can be offered to students. Through such activities, the practical language application skills of business students are enhanced and students can truly get access to authentic business English materials.

\section{B. Communication is the purpose of learning language}

Learners need to focus their attention on language meaning and then learning will be generated. For Business English, Language is more of a very practical means of communication. Krashen argues that when the learner has enough input and understands the input, " $i+1$ " will be generated. Teachers should not shift the focus of teaching to language form. In Business English teaching, students should be concerned about whether the purpose of business communication is reached in language learning and whether the success of communication is achieved. In other words, as long as language exchange is successful, it will produce " $i+1 "$.

C. Creating a low emotional filter environment

The degree of anxiety, self-confidence and motive are the three emotional factors divided by Krashen and they are the three emotional variables that affect the acquisition of L2. Here we discuss the role of emotion in the process of second language acquisition. Krashen argues that those who can learn words better and faster are those who have strong self-confidence, strong motives and greater degree of anxiety. If the effect of emotional filtering is relatively weak, learners can faster acquire language, and it is easier to get more language input. So teachers should actively guide students to take the initiative to learn, cultivate students' interest in Business English in their traditional passive learning and stimulate students' enthusiasm for learning. It is ideal that learners, in the process of learning, are not afraid of making mistakes in order to better and faster acquire the target language and are confidently involved in classroom teaching. In Business English teaching, teachers should try to create a pleasant and relaxing classroom teaching environment, encourage students to boldly express their views, put forward different opinions, constantly make self-correcting and constantly make mistakes in the process. This is the learning process which should be fully understood by students. In Business English teaching, teachers should prompt learners to self-correct in time and in the process of language acquisition, when there is an error, teachers do not have to point out their mistakes as long as it does not affect meaning expression. Hence, harmonious and pleasant teaching atmosphere can better promote learners to subconsciously learn Business English, stimulate their learning motivation, enhance their self-confidence and 
reduce the degree of learning anxiety.

\section{Conclusion}

The key of Krashen's second language acquisition theory lies in emotional filtering and language input, which emphasize language acquisition, and in the aspects of which there exist weaknesses in domestic Business English teaching. Nowadays, there are mixed opinions about Krashen's second language acquisition theory in foreign language teaching, but the application of this theory is of great use and value. Compared with the practice of foreign language teaching, Krashen's second language acquisition theory involves a very different theoretical basis and language environment. Therefore, in Business English teaching, teachers should provide a large number of language input, draw on the positive aspects of Krashen's second language acquisition theory, help students to maximize the acceptance of language input, create an environment of low emotional filter, acquire language and mobilize the enthusiasm of students.

\section{References}

[1] Krashen. S. D. Second Language Acquisition and Second Language Learning [M]. Oxford: Pergamon Press, 1981

[2] Krashen. S. D. Principles and Practice in Second Language Acquisition [M]. New York: Pergamon Press, 1982

[3] Krashen. S. D. The Input Hypothesis: Issues and Implications [M]. Londen: Longman, 1985.

[4] Tian Fengjuan, Liu Haiwei. Application of Krashen's second language acquisition theory in college English teaching [J]. Modern communication, 2016, (08): 207.

[5] Zhang Xin. Application of Krashen second language acquisition theory in college English teaching [J]. Western quality education, 2016, (09): $49+51$.

[6] Zhou Yan. Krashen's second language acquisition theory application in oriented business English practice teaching activities [J]. Journal of Hubei Correspondence University, 2016, (18): 156-157.

[7] Wen Xin. Krashen's second language acquisition theory in secondary school English classroom teaching [J] .Technology and Education, 2015, (10): 107-109. 